\title{
A Transcriptomic Analysis of Sensitive and Tolerant Citrus Rootstocks under Natural Iron Deficiency Conditions
}

\author{
Concetta Licciardello', Biagio Torrisi, Maria Allegra, Fabiola Sciacca, Giancarlo Roccuzzo, \\ Francesco Intrigliolo, and Giuseppe Reforgiato Recupero \\ Consiglio per la Ricerca e la Sperimentazione in Agricoltura-ACM, Corso Savoia 190, 95024, \\ Acireale (CT), Italy \\ Paola Tononi and Massimo Delledonne \\ Department of Biotechnology, University of Verona, Strada Le Grazie 15, 37134, Verona, Italy \\ Vera Muccilli \\ Department of Chemical Science, University of Catania, V.le A. Doria 6, 95126, Catania, Italy
}

Additional INDEX words. Carrizo citrange, chlorosis, Citrus sinensis, microarray, Swingle citrumelo

\begin{abstract}
Iron chlorosis is one of the most serious abiotic stresses affecting citrus (Citrus sp.) culture in the Mediterranean Basin. A trial was performed with potted tolerant and sensitive rootstocks that were grown in volcanic and calcareous soils. Microarray analysis allowed for the identification of differentially expressed genes putatively involved in iron (Fe) deficiency. Most of the differentially expressed genes isolated from the root tips were of unknown function; the remaining genes were related to the oxidative stress response (e.g., glutathione peroxidase), hormone metabolism and signaling (e.g., small auxin up RNA family protein genes), biological regulation, protein turnover, and the tricarboxylic acid cycle (e.g., aconitase). Additionally, the majority of the Fe stress-related genes expressed in the sensitive Swingle citrumelo (Citrus paradisi $\times$ Poncirus trifoliata) and tolerant Carrizo citrange (Citrus sinensis $\times P$. trifoliata) rootstocks identified using real-time reverse transcription-polymerase chain reaction (RT-PCR) were related to regulation, the oxidative stress response, and hormone metabolism and signaling, thereby confirming the array data. Furthermore, validation of the differentially expressed genes in seven tolerant and sensitive rootstocks grown in a field trial under chlorotic conditions was performed. In general, the gene expression profiles reflect the different responses of rootstocks, possibly as a result of the various genetic mechanisms involved in the response to Fe deficiency. Moreover, the expression of aconitase was analyzed in the roots and juice to evaluate the implication of the different aconitase isoforms (Aco), which are derived from specific cellular compartments, in the different tissues. The involvement of the mitochondrial isoform (Aco2) was directly correlated with the acidity of the juice, whereas the cytosolic one (Aco3), which corresponds to the aconitase isolated during the microarray analysis, was found specifically in the roots.
\end{abstract}

Iron deficiency chlorosis is a worldwide problem that mainly affects fruit crops such as citrus, deciduous fruit trees, and grapevine [Vitis vinifera (Mengel et al., 2001)] that are grown in calcareous soils (Marschner, 1995; Mengel et al., 2001). Approximately $20 \%$ to $50 \%$ of the fruit trees in the Mediterranean Basin suffer from Fe deficiency (Jaegger et al., 2000) caused by high soil concentrations of calcium and bicarbonate. Although $\mathrm{Fe}$ is quite abundant, it is often a limiting resource for plant growth as a result of its low availability (Guerinot and $\mathrm{Yi}$, 1994) and low solubility in well-aerated environments (Donnini et al., 2010). This condition affects the metabolic processes in leaves and roots and leads to reduced Fe availability (Mengel, 1994) and the development of $\mathrm{Fe}$ chlorosis symptoms. The most common $\mathrm{Fe}$ chlorosis symptoms include interveinal chlorosis in young leaves (Abadía and Abadía, 1993; Morales et al., 1998), decreased leaf net photosynthetic rate (Briat et al., 1995), reduced leaf size and thickness, increased leaf fragility,

Received for publication 31 May 2013. Accepted for publication 12 Sept. 2013. We thank Diego Reforgiato for his technical assistance in the TGICL clustering and assembly analysis and Alberto Ferrarini for his direction of the CombiMatrix array procedures.

${ }^{1}$ Corresponding author. E-mail: concetta.licciardello@entecra.it. and plant growth retardation and stasis followed by death in more severe conditions. Lime-induced Fe deficiency causes reductions in yield (Pestana et al., 2003), delayed fruit ripening, and impaired fruit quality as previously reported for peach [Prunus persica (Sanz et al., 1997)] and sweet orange [Citrus sinensis (Pestana et al., 2011)]. Severe reductions in yield are associated with decreased leaf chlorophyll concentrations in peach, kiwifruit (Actinidia deliciosa), and pear (Pyrus communis) trees grown in calcareous soils (Rombolà et al., 1999). A possible solution is Fe treatment, which results in yield increases for peach (Pérez-Sanz et al., 2002), olive [Olea europaea (Fernandez-Escobar et al., 1993)], and kiwifruit (Loupassaki et al., 1997) trees.

Fe deficiency can be rapidly reversed by the addition of inorganic $\mathrm{Fe}$ salts, synthetic chelates, and natural organic compounds (Abadía et al., 2004). Because fertilizers are also quite costly, the easiest way to avoid $\mathrm{Fe}$ chlorosis from calcareous soils in fruit trees is through the use of tolerant rootstocks. Plants of the Citrus genus are considered susceptible to Fe chlorosis (Carpena-Artes et al., 1995), and the tolerance or sensitivity to Fe chlorosis varies in different rootstocks with a considerable phenotypic variability. For example, trifoliate orange (Poncirus trifoliata) and Swingle citrumelo are considered very 
susceptible, whereas Carrizo citrange is considered tolerant, and sour orange (Citrus aurantium), various mandarins (Citrus reticulata, Citrus nobilis), Rangpur lime (Citrus limonia), and rough lemon (Citrus jambhiri) are considered very tolerant (Hamze et al., 1986). In addition, although the sour orange is the most widely distributed and common rootstock in the Mediterranean area and it has adapted to calcareous soils, its sensitivity to the citrus tristeza virus (CTV), one of the most serious biotic stressors, limits the use of the sour orange rootstock.

In this study, microarray analysis was performed to investigate differences in gene expression in the citrus transcriptome between sensitive and tolerant rootstocks with the aim of identifying genes that could potentially play roles in sensitivity or tolerance to chlorosis conditions. In addition, the expression levels of some genes were used to monitor the degree of Fe deficiency in trees that had been grafted onto seven sensitive and tolerant field-grown rootstocks (Reforgiato Recupero et al., 2009).

\section{Materials and Methods}

Plant material. 'Tarocco Scirè' sweet orange was grafted onto 2-year-old seedlings of Swingle citrumelo (SC) and Carrizo citrange (CC), which are highly sensitive and tolerant to Fe chlorosis, respectively. The trees were grown for 3 years in plastic pots containing volcanic or calcareous soil $(0 \%$ or $10 \%$ active lime, respectively). Ten grafted trees were used for each rootstock and soil condition. The parameters of the soil composition in the pots are indicated in Table 1 . In $2009, \approx 5 \mathrm{~g}$ of fresh root tips ( $5 \mathrm{~mm}$ long) was taken from three biological replicates (one plant per replicate for each rootstock and soil condition for a total of 12 plants) and was used for molecular and chemical analysis. In 2011, another experiment was conducted on field-grown trees at our center's experimental farm at Palazzelli, Sicily, Italy (Reforgiato Recupero et al., 2009). Rootstock roots and scion leaves were taken from the plants of the cultivar Tarocco TDV and were grafted on seven rootstocks that exhibited different and extreme behaviors in response to Fe deficiency (Table 2). Three replicates were used to minimize the influence of other biotic and abiotic stresses.

Total RNA EXtraction. Total RNA was extracted from $0.1 \mathrm{~g}$ of the root tips from each biological replicate of $\mathrm{SC}$ and $\mathrm{CC}$ grown in plastic pots using the Spectrum ${ }^{\text {TM }}$ Plant Total RNA Kit (Sigma-Aldrich, St. Louis, MO). RNA quantity was evaluated using a spectrophotometer (NanoDrop 100; Thermo Fisher Scientific, Wilmington, DE), and RNA integrity was determined using an Agilent 2100 Bioanalyzer (Agilent Technologies, Santa Clara, CA). The same RNA samples were used for chip hybridization and RT-PCR experiments for the validation

Table 1. Mean values of main physical and chemical parameters related to volcanic and calcareous soils used on pot-grown citrus rootstocks.

\begin{tabular}{|c|c|c|}
\hline Parameter & Volcanic soil & Calcareous soil \\
\hline Clay $\left(\mathrm{g} \cdot \mathrm{kg}^{-1}\right)$ & 50 & 80 \\
\hline Silt $\left(\mathrm{g} \cdot \mathrm{kg}^{-1}\right)$ & 120 & 100 \\
\hline Sand $\left(\mathrm{g} \cdot \mathrm{kg}^{-1}\right)$ & 830 & 820 \\
\hline $\mathrm{pH}$ & 6.3 & 8.7 \\
\hline Active lime $\left(\mathrm{g} \cdot \mathrm{kg}^{-1}\right)$ & - & 100 \\
\hline Total $\mathrm{CaCO}_{3}\left(\mathrm{~g} \cdot \mathrm{kg}^{-1}\right)$ & - & 530 \\
\hline Organic matter $\left(\mathrm{g} \cdot \mathrm{kg}^{-1}\right)$ & 1.5 & 2 \\
\hline Assimilable iron $\left(\mathrm{mg} \cdot \mathrm{kg}^{-1}\right)$ & 11 & 4.8 \\
\hline
\end{tabular}

Table 2. Citrus rootstocks used for analysis in the grove and their relative responses to iron deficiency.

\begin{tabular}{ll}
\hline Rootstock & Sensitivity/tolerance \\
\hline Citrus aurantium Cassibile 2 & Tolerant \\
Citrus latipes $\times$ C. aurantium $13-23$ & Tolerant \\
C. latipes $\times$ C. aurantium $14-37$ & Tolerant \\
Carrizo citrange & Tolerant \\
Swingle citrumelo & Highly sensitive \\
C. latipes $\times$ Poncirus trifoliata $5-3$ & Sensitive \\
C. latipes $\times P$. trifoliata 6-17 & Sensitive \\
\hline
\end{tabular}

of the gene expression data. Total RNA was extracted from $0.1 \mathrm{~g}$ of the root tips and leaves using the RNase Plant Mini kit (Qiagen, Valencia, CA) and from $3 \mathrm{~mL}$ of sweet orange juice (Ancillo et al., 2007) from three biological replicates of the seven rootstocks in the field trial. All total RNA samples were treated with DNase (Promega, Madison, WI) for $30 \mathrm{~min}$ at $37^{\circ} \mathrm{C}$. The amount and quality of the total RNA were estimated using a spectrophotometer and gel electrophoresis with ethidium bromide staining, respectively. RNA samples were used for real-time RT-PCR experiments.

Microarray ANALYSIS. Expression analysis was performed on a custom 90K microarray (CombiMatrix; CustomArray, Bothell, WA), which contained 7697 specific probes 35 to $40 \mathrm{bp}$ in length that were designed using the OligoArray 2.1 software (Rouillard et al., 2003). The probes were based on the clustering and assembly of 33,990 expressed sequence tag (EST) sequences derived from different types of libraries constructed from the roots of Citrus and its relatives. All the sequences were derived from the National Center for Biotechnology Information (NCBI) databases (release Apr. 2009), and the assembly and clustering was performed with the TIGR Gene Indices clustering tools [TGICL (Pertea et al., 2003)]. Oligos were synthesized, and 11 replicates were distributed to random, nonadjacent positions on the chip. Three biological replicates were analyzed for each sample. Reverse transcription, amplification, and labeling were performed using the RNA AmpULSe amplification and labeling kit according to the manufacturer's instructions (Kreatech Diagnostics, Amsterdam, The Netherlands). Five micrograms of purified labeled aRNA were hybridized to the array according to the manufacturer's protocol. The array was scanned with a scanner (Axon GenePix 4400A; Molecular Devices, Sunnyvale, CA). Data extraction was performed with the GenePix Pro 7 software (Molecular Devices). The signal background was calculated as the mean of the negative controls plus twice the SD. The normalization between the arrays was performed according to the quantile method (Bolstad, 2001). Genes were excluded from further analysis if the $\mathrm{CV}$ between the biological replicates was greater than 0.5. Analysis of the differentially expressed genes was performed according to the linear modeling and empirical Bayes methods, as implemented in the Limma $\mathrm{R}$ package (Smyth, 2005). Probability values were adjusted for multiple testing according to Benjamini and Hochberg (1995). Genes were considered significant when the false discovery rate was 0.05 or less and the $\log 2$ fold change was 0.66 or greater or -0.66 or less. The expression data are available at the NCBI GEO database (Edgar et al., 2002) under the accession number GSE38667. The functional annotation was performed with the Blast2GO software using the BlastX algorithm and the non-redundant 
database. Annotation was also performed using the sweet orange draft genome (Sweet Orange Genome Project, 2010).

REAL-TIME RT-PCR GENE EXPRESSION ANALYSIS. The validation of the gene expression data was performed using realtime RT-PCR according to Licciardello et al. (2008). The primer pair sequences were designed to correspond with (when possible) or in the proximity of the probe used in the microarray chip. The primer sequences are listed in Table 3. Expression analysis of the roots, leaves, and juice tissues was conducted to evaluate the involvement of the aconitase isoforms (Aco1, Aco2, and Aco3) using the oligos previously reported by Terol et al. (2010).

SPAD INDEX AND CHLOROPHYLL CONTENT. Leaf greenness was monitored using a portable chlorophyll meter (SPAD-502; Minolta, Osaka, Japan). Ten leaves per tree were sampled for $\mathrm{Fe}$ determination. The readings from the midareas of the fully expanded spring leaves were expressed in SPAD units and were evaluated according to Intrigliolo et al. (2000). Leaf chlorophyll concentration (Chltot) was determined as the sum of the chlorophyll $\mathrm{a}$ and $\mathrm{b}$ contents in the leaf portion that was subjected to SPAD measurement. The pigments were extracted with dimethyl sulfoxide and incubated in the dark at $65{ }^{\circ} \mathrm{C}$ for various time points, depending on the degree of cutinization and leaf thickness (Hiscox and Israelstam, 1979). The chlorophyll a and b content was estimated spectrophotometrically at 663 and $645 \mathrm{~nm}$, respectively. Chlorophyll levels were calculated using the equations described by Arnon (1949), and the concentration was expressed relative to the fresh leaf weight (Nxawe et al., 2011).

Peroxidase activity. Two grams of fresh young leaves from the control and Fe-deficient plants and 5 to $8 \mathrm{~mm}$ of the root tips sampled during the same period were homogenized with a Polytron 3100 (Kinematica, Luzern, Switzerland) in cold $0.05 \mathrm{M}$ Na-phosphate buffer ( $\mathrm{pH} 6.5$ ) containing $1.5 \% \mathrm{NaCl}$, $0.3 \%$ polyethylene glycol 6000 , and $2.5 \%(\mathrm{w} / \mathrm{v})$ insoluble polyvinylpolypyrrolidone. The ratio between the leaf fresh weight and the extraction buffer volume was 1:6(w/v). Peroxidase (POD) activity was measured according to Ngo and Lenhoff (1980). Adequate amounts of the crude enzyme extract were added to $3 \mathrm{~mL}$ of $0.1 \mathrm{M} \mathrm{Na}$-phosphate buffer ( $\mathrm{pH} 6.5$ ) containing $0.2 \mathrm{mM}$ 3-methyl-2-benzothiazolinone hydrazone hydrochloride hydrate, $10 \mathrm{~mm}$ 3-dimethylamino benzoic acid, and $0.3 \mathrm{~mm} \mathrm{H}_{2} \mathrm{O}_{2}$. Absorbance changes were recorded at $590 \mathrm{~nm}$ using a spectrophotometer (ultraviolet-1601; Shimadzu, Kyoto, Japan) at room temperature. One unit of POD activity was defined as an increase of one unit of absorbance per minute (Chouliaras et al., 2004).

Evaluation OF FERric CHELATE REDUCTASE. The degree of tolerance to Fe deficiency was evaluated by measuring the root ferric chelate reductase (FCR) activity; this reaction measures the formation of the Fe II-bathophenantroline disulphonate complex from Fe III-ethylenediaminetetraacetic acid (EDTA) (Bienfait et al., 1983). The FCR activity was estimated according to Albano and Miller (1996) from 5 to $8 \mathrm{~mm}$ of root tips that were sampled at the same time as the leaves. A root-free solution was analyzed and served as a negative control.

Statistical analysis. Data related to FCR, POD, Fe, Chltot, and SPAD were analyzed using the analysis of variance. The means were separated by Tukey's honestly significant difference test with the Statistica 6.0 software package (StatSoft, Padova, Italy).

\section{Results and Discussion}

\section{Trees growing in pots}

RESPONSES OF ROOTS AND LEAVES to Fe DEFICIENCY. Typical symptoms of chlorosis were evident mainly in the SC plants on root collection (Fig. 1). FCR activity was increased in both types of rootstock when plants were grown in calcareous conditions (0.053 vs. $0.031 \mu \mathrm{mol} \cdot \mathrm{g}^{-1} \cdot \mathrm{h}^{-1} \mathrm{Fe}^{2+}$ fresh weight) (Table 4). Furthermore, Fe-deficient plants developed more lateral roots and abundant root hairs (Fig. 1) in accordance with previous studies (Römheld and Kramer, 1983; Römheld and Marschner, 1981). To monitor the effects of Fe deficiency, POD activity was analyzed in both the roots and scion leaves (Table

Table 3. Primer pairs used in real-time reverse transcription-polymerase chain reaction experiments to validate differentially expressed genes isolated after chip hybridization.

\begin{tabular}{|c|c|c|}
\hline Primer name & Forward $\left(5^{\prime}-3^{\prime}\right)$ & Reverse $\left(5^{\prime}-3^{\prime}\right)$ \\
\hline id_202 & TCAAGGGCTGTAACAAAGTAAATTTAAG & TTTCAGAGATAAACATCAGTTGCATCT \\
\hline id_408 & GCCCGGGCATCAAATTAATT & ACCGATCAAGCATCGAGGAT \\
\hline id_1208 & GCAACAAGAGTGGCCAAGTCA & CTTCCTGAGCCAGAAGTTCTTGA \\
\hline id_1806 & TTTGACCTTTTTGCCTGAAGCT & CTGGTGGAAAAACAGAAGACTTTCT \\
\hline id_1958 & CGGATTCAATCGGTACTATATTTGAC & TCACCCACTCGGAAAGATTTG \\
\hline id_1994 & GCTGGTTGTAAGTTGTTGGAAATA & GTTTTCATCCTCCTCCATCTTCA \\
\hline id_2189 & TTCGTCGACCCAGGATGTG & TCATTGGAGATGGGCTAAGGA \\
\hline id_3325 & ATGGCAATGCTGAAACCAGTT & GGCAAATCAAGTTCTCTCACAAATATT \\
\hline id_3363 & TGAAGATCCTCCTGACTGTAAAACC & САААТССТТТСТССТТССТСАСА \\
\hline id_3576 & CATCGCCGTCGGTTTCC & TCAGCCTAGAATTAGATCCTCGAATAT \\
\hline id_4207 & TGCCATTTATACATGTTTCTCGTTCT & CAAAGCTGACTTGAGAGAGGTACACA \\
\hline id_4258 & CCACGACCTAAAAGAATTAGACAACTC & ATAGATTGAAATTGAGAAGCGTACTTACA \\
\hline id_6938 & ATGGTTGAGCCGAGGATGAA & TCATGGGCAGCAAACTGTGA \\
\hline id_7406 & GAATGATGACTGTGAGCATTTCG & CCTCCTGATTTGCTCGAGTACA \\
\hline
\end{tabular}




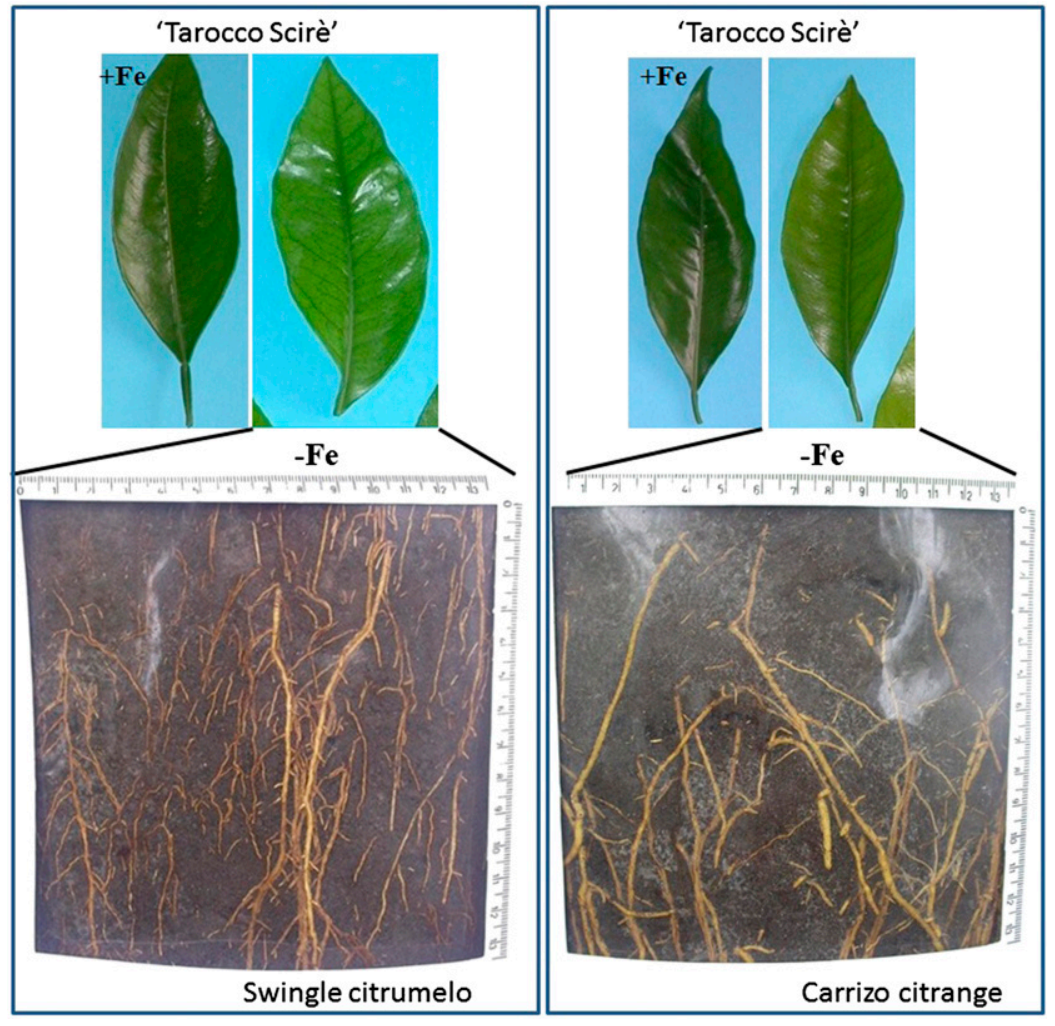

Fig. 1. Leaves of 'Tarocco Scirè' sweet orange grafted on Swingle citrumelo (SC) and Carrizo citrange (CC) rootstocks grown under volcanic $(+\mathrm{Fe})$ and calcareous $(-\mathrm{Fe})$ soil. Images of a section of soil with roots of SC and CC in pots contained volcanic and calcareous soil.

4). Higher POD activity was observed in the roots, but not the leaves, of CC when compared with SC. In regard to the soil effect (Table 4), higher FCR values and lower POD (roots and leaves), Chltot, and SPAD were observed in the calcareous soil compared with the volcanic soil, which is in agreement with previous results and is typical of Fe deficiency under stress conditions (Forner-Giner et al., 2010).

IDENTIFICATION OF DIFFERENTIAL GENE EXPRESSION USING a CombiMatrix platform. To identify genes that were differentially expressed in response to Fe deficiency stress, root tips were collected from plants grown in calcareous soil with $10 \%$ active lime as soon as the leaves exhibited the initial signs of chlorosis (yellow central veins). As expected, the symptoms were more obvious in SC than in CC. Differences in root gene expression were deduced using a genomewide expression analysis according to the experimental design indicated in Figure 2; this analysis was performed on a custom array specific for citrus root ESTs that was developed with the $90 \mathrm{~K}$ CombiMatrix technology. The chip allowed for the analysis of 7697 transcripts. The use of a custom array of transcripts specific to the roots of Citrus and related genera (retrieved from NCBI) was intended to determine the Fe-mediated transcriptional responses in a specific set of genes. A total of 31 differentially expressed genes were identified from the comparisons. The experimental design (Fig. 2) allowed for the isolation of genes that differed in response to specific soil conditions (with and without active lime) in relation to the genotype behavior. The low fold change (0.66) threshold used to identify differential genes was justified by the use of the CombiMatrix platform, which underestimates gene expression to a certain extent when compared with other platforms (Git et al., 2010).

The manual annotation of the 31 differentially expressed transcripts (Table 5) was based on results from the Blast2GO software (Conesa et al., 2005) and on the sweet orange genome (Sweet Orange Genome Project, 2010). Of the genes identified in the total differential gene expression analysis, $34.3 \%$ were predicted but not annotated. The remaining $65.7 \%$ belonged to various functional categories (Table 5). The reduced number of expressed genes under calcareous conditions confirmed previous findings (Forner-Giner et al., 2010; Zamboni et al., 2012), and generally it could be influenced by the conditions of stringency of the used custom array.

Table 5 reports the genes that were differentially expressed in both rootstocks when grown under calcareous conditions. A total of 25 genes were identified; 14 genes were up-regulated, and 11 were down-regulated. The categories involved are reported in Figure 3A.

Table 6 shows the genes that were differentially expressed between SC and CC when both were grown in volcanic soil. A total of nine genes were identified; six genes were up-regulated, and three were down-regulated. The categories involved are reported in Figure 3B.

Table 4. Analysis of parameters to evaluate the effect of Swingle citrumelo (SC) and Carrizo citrange (CC) regardless of soil (rootstock) and calcareous and volcanic soil regardless of rootstocks (soil). ${ }^{\mathrm{z}}$



${ }^{\mathrm{z}}$ Ferric-chelate reductase (FCR) was determined on roots; total content of chlorophyll $\left(\mathrm{Chl}_{\mathrm{tot}}\right)$ and SPAD on the scion leaves; peroxidase (POD) was evaluated on roots and leaves.

$* * * P \leq 0.001 ; * * P \leq 0.01 ; * P \leq 0.05$; absence of asterisk indicates absence of significance.

$\mathrm{FW}=$ fresh weight. 


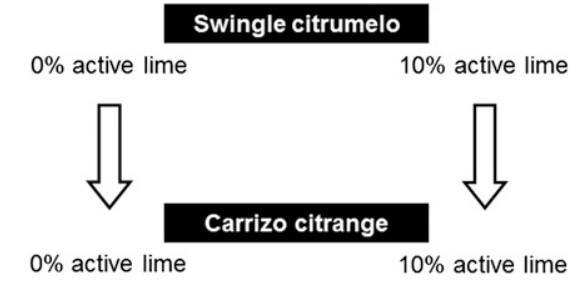

Fig. 2. Schematic diagram of experimental design used for the hybridization of the custom 90K microarray (CombiMatrix; CustomArray, Bothell, WA). Arrows indicate the direction of comparison for expression analysis regarding plants of Swingle citrumelo and Carrizo citrange grown in pots with $0 \%$ and $10 \%$ of active lime.

Real-time RT-PCR experiments were performed on all the differentially expressed genes and generally confirmed the array results, as shown in Table 7.

Differential gene eXPRESSion profiles SPECIFIC TO CALCAREOUS SOIL. The genes that were differentially expressed in the $\mathrm{SC}$ and $\mathrm{CC}$ rootstocks grown in calcareous soil were mostly involved in the oxidative stress response. It could be hypothesized that the increases in glutathione peroxidase (GPX, id_2509), oxalate oxidase (id_408), and germin-like (id_4207) in the sensitive rootstock could help to alleviate reactive oxygen species (ROS) damage produced under Fe deficiency (Rellán-Álvarez et al., 2010).

In the present study, microarray and relative real-time RTPCR expression data confirmed the overexpression of GPX (id_2509) in Swingle citrumelo compared with Carrizo citrange in calcareous soil (Table 7). Peroxidase family members catalyze $\mathrm{H}_{2} \mathrm{O}_{2}$ reduction by transferring electrons to glutathione. As a result of the very heterogeneous regulation of their expression, plant peroxidases are involved in a broad range of physiological processes such as lignification, suberization, auxin metabolism, crosslinking of cell wall proteins, salt tolerance, and oxidative stress (Passardi et al., 2005). GPX expression is generally up-regulated in response to stresses such as Fe deficiency (Almansa et al., 2002) and as a defense response to most metals, which can damage or disturb the normal functions of plants (Fang and Kao, 2000). Stress stimulates ROS production, and plants react to this stress by synthesizing GPX to neutralize the oxidative environment. In citrus plants, the Fe-related reduction in POD activity coincides with a reduced catalase activity (Chouliaras et al., 2004; Forner-Giner et al., 2010), because both enzymes are involved in $\mathrm{H}_{2} \mathrm{O}_{2}$ metabolism. This indicates that the reduced levels of POD activity in the roots and leaves of the plants grown in Fedeficient soils (16.98 and $13.49 \mu \mathrm{mol} \cdot \mathrm{g}^{-1} \cdot \mathrm{h}^{-1} \mathrm{Fe}^{2+}$ fresh weight, respectively, in the roots and the leaves, indicated in Table 4) lead to increased ROS levels, which could lead to oxidative stress. The corresponding higher level of POD in the roots of $\mathrm{CC}$, with respect to $\mathrm{SC}$ (25.62 in Table 4), might indicate a mechanism to prevent damage from $\mathrm{Fe}$ deficiency-induced oxidative stress, and this increased activity could be used as an indicator of Fe deficiency tolerance (Forner-Giner and Ancillo, 2011).

The array data revealed the overexpression of oxalate oxidase (id_408) in the sensitive rootstock compared with the tolerant rootstock under stress conditions (Table 5). These data were confirmed using real-time RT-PCR (Table 7); however, these data are not in agreement with a previous report (RellánÁlvarez et al., 2010). Although the implications of the current finding are still unknown, a role for oxalate as a regulatory component of $\mathrm{Fe}$ acquisition in Fe-deficient conditions must be considered (Pedas et al., 2008).

The overexpression of germin-like transcript (id_4207) in $\mathrm{SC}$, with respect to $\mathrm{CC}$, in the calcareous soil (Table 5), which was confirmed using real-time RT-PCR (Table 7), is in agreement with previous observations from an analysis of the tomato (Solanum lycopersicum) root proteome (Brumbarova et al., 2008). The positive modulation of the germin protein reported in this proteomic study was justified hypothesizing its role in producing hydrogen peroxide for apoplastic $\mathrm{Fe}$ reduction or under general stress response conditions.

A portion $(8 \%)$ of the genes differentially expressed in the rootstocks under chlorotic conditions was related to hormone metabolism and signaling. The role of plant hormones in the regulation of $\mathrm{Fe}$ deficiency responses has been extensively studied (Romera et al., 2011). The plant hormone auxin appears to be a central player in the regulation of many developmental steps required for lateral root formation (Peret et al., 2009) and the modulation of the length, position, and abundance of root hairs (Perry et al., 2007). Moreover, low Fe availability frequently leads to the formation of branched root hairs (Muller and Schmidt, 2004) through a signaling cascade that likely involves auxin and ethylene (Schmidt et al., 2003). In the present study, the small auxin up RNA (SAUR) protein family gene (id_2189) was overexpressed in SC plants grown in calcareous soil compared with CC plants grown in calcareous soil (Table 5). Real-time RT-PCR analysis confirmed the microarray data (Table 7), indicating the involvement and the induction of the SAUR gene family under Fe stress conditions (Zheng et al., 2009). Moreover, the expression data were also supported by observations of the root architecture (Fig. 1); the secondary roots of $\mathrm{SC}$ were more highly developed than those of CC. It has been reported that auxin may play a role as an upstream signal in the modulation of Fe-deficiency responses in dicots (Chen et al., 2010), and morphological alterations that resemble developmental responses to Fe deficiency (Schmidt et al., 2003) have been well documented.

Among the down-regulated genes in SC, with respect to $\mathrm{CC}$, under chlorotic stress conditions, the most interesting genes were NADH glutamate dehydrogenase (NADH-GDH, id_6450) and calmodulin (CaM, id_3325), which were included in the Transport category (Fig. 3A). The reduced expression of NADH-GDH, which is part of the tricarboxylic acid cycle (Tables 5 and 7), could be considered an indication of the difficulties that the sensitive rootstocks have in relation to energetic metabolism under stress conditions (Robinson et al., 1991). The role of NADH-GDH under stress conditions could play an alternative role in ammonium assimilation during Fe deficiency, as described in bean [Phaseolus vulgaris (Slatni et al., 2008)]. In particular, ammonium assimilation through the GDH pathway occurs under conditions of metal deficiency such as aluminium and phosphorous as an adaptive response to environmental stress (Melo-Oliveira et al., 1996; Srivastava and Singh, 1987).

$\mathrm{CaM}$ is a calcium sensor that mediates intracellular $\mathrm{Ca}^{2+}$ signaling and regulates various cellular processes. CaM induction under Fe deficiency is poorly documented. The downregulation of $\mathrm{CaM}$ under Fe-deficient conditions might suggest a direct involvement of CaM in the transduction of the Fe deficiency signal or in the induction and regulation of the metabolic changes that accompany the responses induced by Fe deficiency, as suggested by Vigani et al. (2012). 


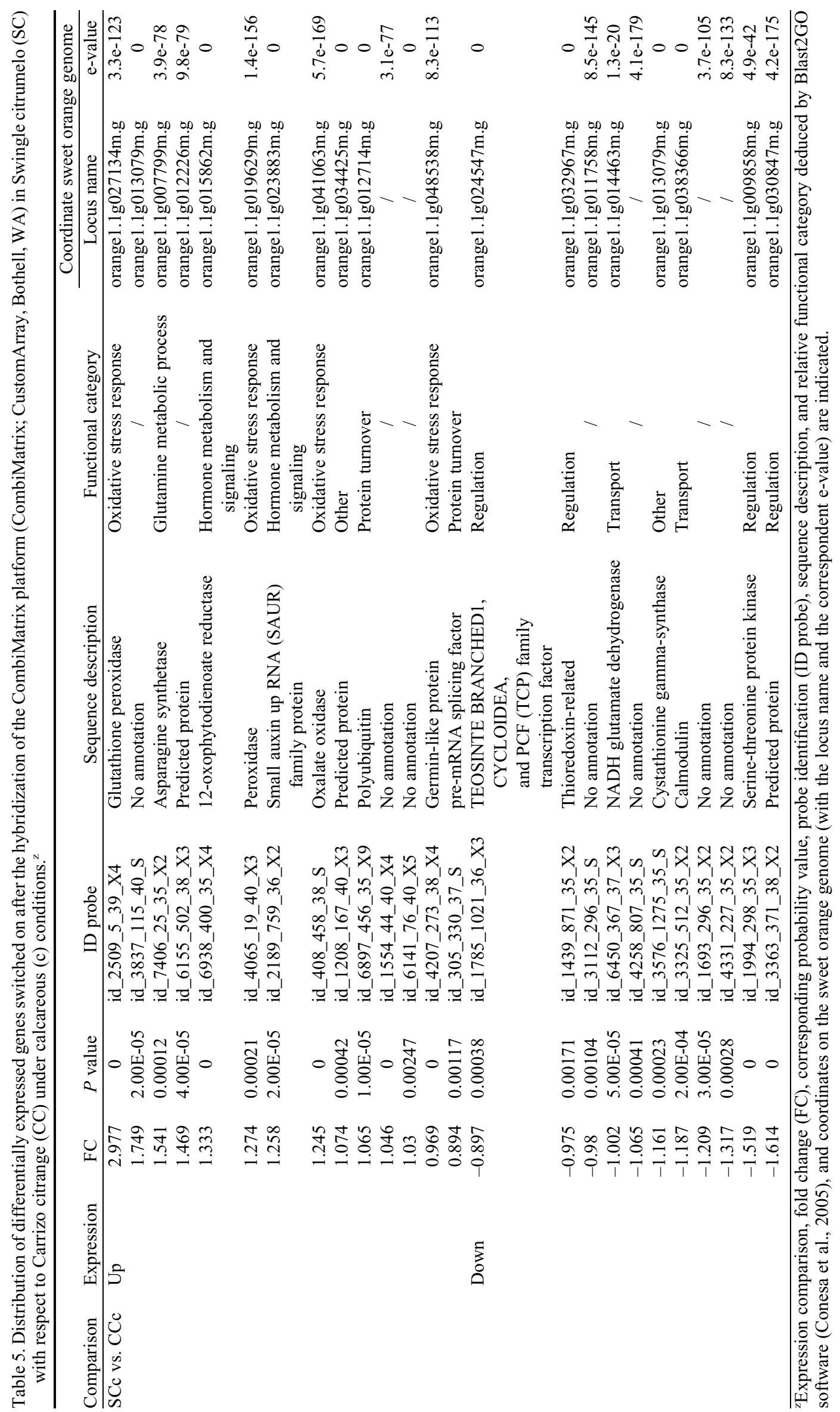



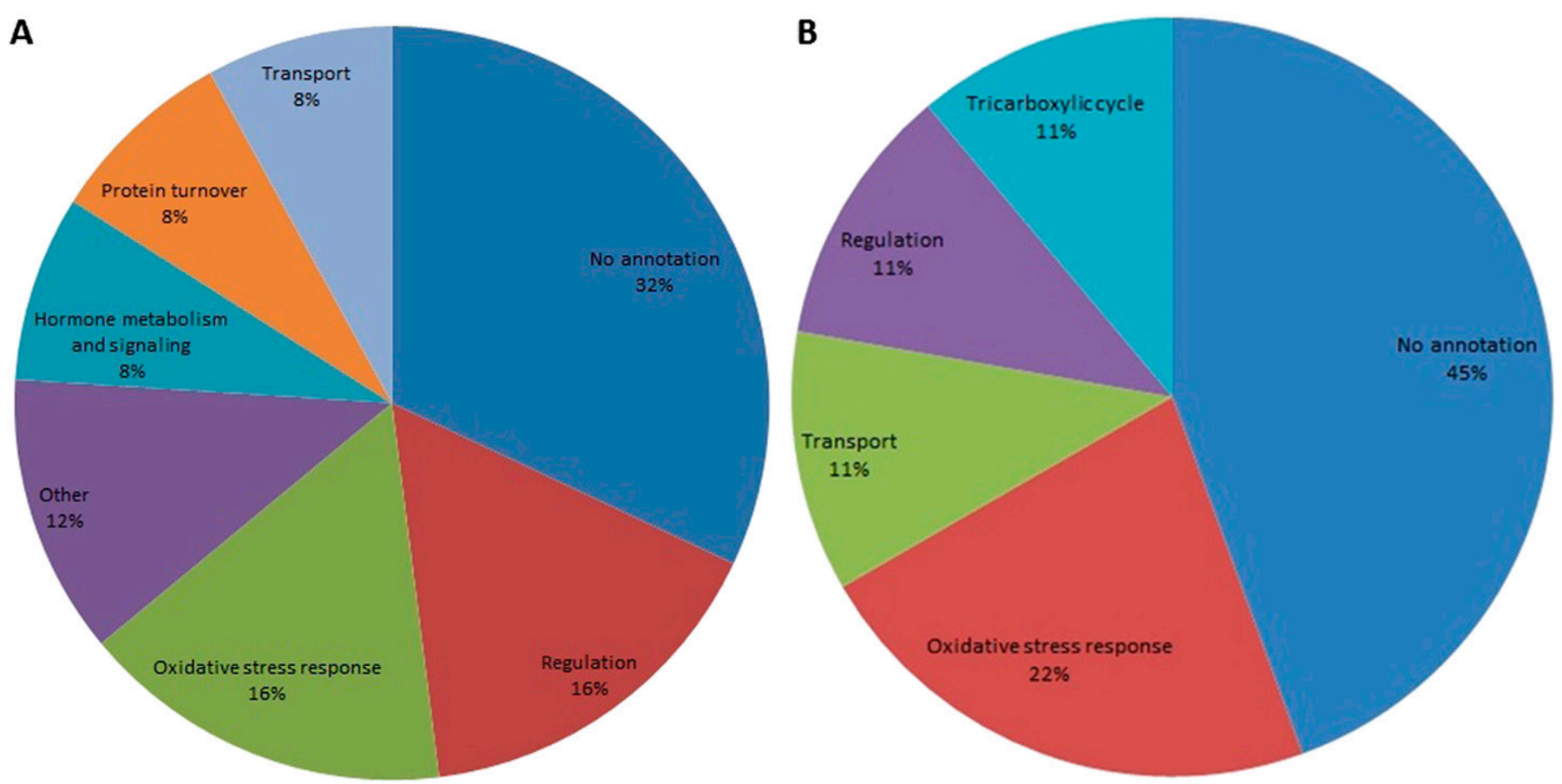

Fig. 3. Functional classification of differential expressed genes in Swingle citrumelo compared with Carrizo citrange in calcareous soil (A) and in a volcanic one (B).

Although Table 7 shows that the RT-PCR ratio generally correlates with the microarray fold change data, there were two genes, id_1208 and id_6141, that were identified as overexpressed in the microarray analysis and were identified as downregulated in the real-time RT-PCR experiment. Although both microarray and real-time RT-PCR technologies are sensitive and specific in the isolation of the differentially expressed genes, it is possible a no correspondent expression. This may be attributable to cross-hybridization among the genes in the microarray analysis; however, this situation is not likely to occur during realtime RT-PCR analysis, suggesting that the RT-PCR data may be more accurate (Klok et al., 2002).
DifFERENTIAL GENE EXPRESSION PROFILES SPECIFIC TO volCANIC solL. The volcanic soil, as the control condition, activated the expression of genes (Table 6) that were not directly responsible for the sensitivity or tolerance to the $\mathrm{Fe}$ deficiency. These genes could be specific to the genotype such as oxalate oxidase and germin-like, which were also overexpressed in the previous comparison. The only gene that could be considered interesting is aconitase (id_1806), which is involved in the acidification process of the roots, and this gene is usually expressed under conditions of Fe deficiency. The real-time RT-PCR (Table 7) confirmed the down-regulation of this gene in the sensitive rootstocks even in the volcanic soil.

Table 6. Distribution of differentially expressed genes switched on after hybridization of custom 90K microarray (CombiMatrix; CustomArray, Bothell, WA) in Swingle citrumelo (SC) with respect to Carrizo citrange (CC) under volcanic (v) conditions. ${ }^{\mathrm{z}}$

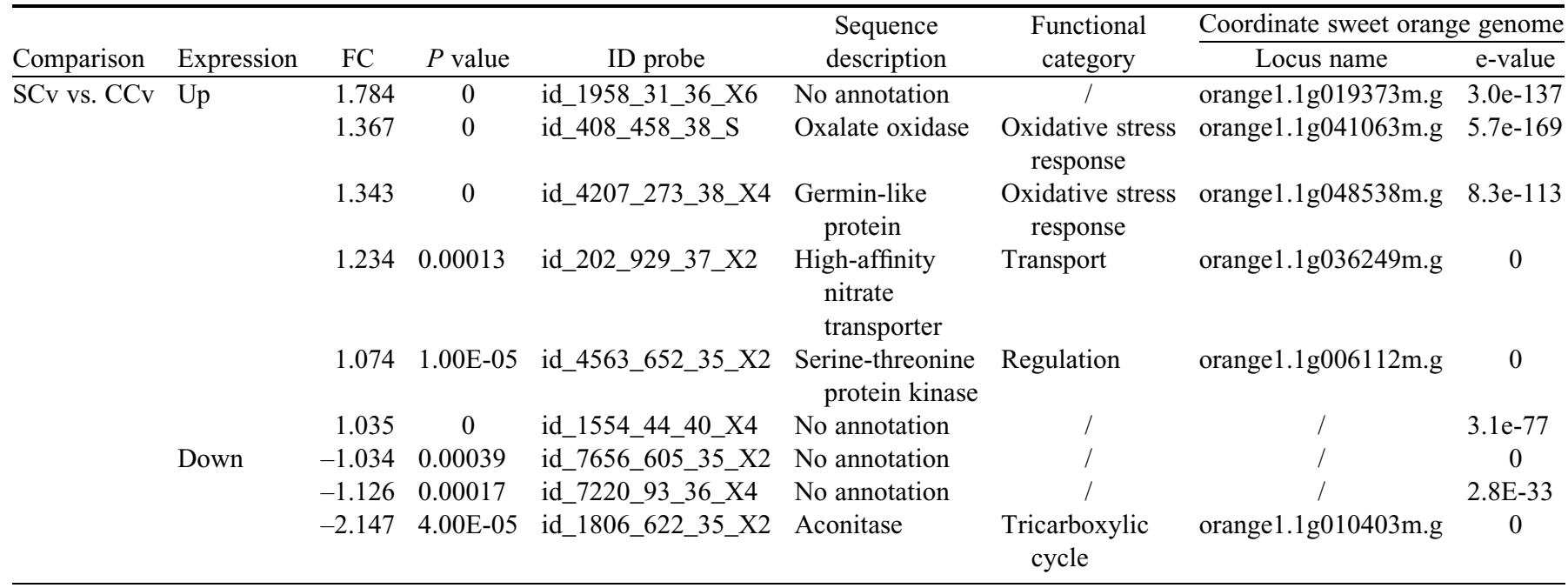

${ }^{\mathrm{z}}$ Expression comparison, fold change (FC), corresponding probability value, probe identification (ID probe), sequence description, and relative functional category deduced by Blast2GO software (Conesa et al., 2005), and coordinates on the sweet orange genome (with the locus name and the correspondent e-value) are indicated. 
Table 7. Transcripts modulated in iron-deficiency sensitive Swingle citrumelo (SC) and tolerant Carrizo citrange (CC) rootstocks in response to calcareous (c) and volcanic (v) soil. ${ }^{\mathrm{z}}$

\begin{tabular}{|c|c|c|c|c|}
\hline Comparison & ID probe $^{y}$ & Sequence description & FC microarray & Real-time RT-PCR ratio \\
\hline \multirow[t]{11}{*}{ SCc vs. CCc } & id_2509_5_39_X4 & Glutathione peroxidase & 2.977 & 3.397 \\
\hline & id_6938_400_35_X4 & 12-oxophytodienoate reductase & 1.333 & 1.147 \\
\hline & id_408_458_38_S & Oxalate oxidase & 1.245 & 2.513 \\
\hline & id_1208_167_40_X3 & Predicted protein & 1.074 & -1.105 \\
\hline & id_6141_76_40_X5 & No annotation & 1.03 & -1.007 \\
\hline & id_6450_367_37_X3 & NADH glutamate dehydrogenase & -1.002 & -2.713 \\
\hline & id_4258_807_35_S & No annotation & -1.065 & -2.326 \\
\hline & id_3576_1275_35_S & Cystathionine gamma-synthase & -1.161 & -2.050 \\
\hline & id_3325_512_35_X2 & Calmodulin & -1.187 & -1.236 \\
\hline & id_1693_296_35_X2 & No annotation & -1.209 & -1.221 \\
\hline & id_4331_227_35_X2 & No annotation & -1.317 & -2.769 \\
\hline \multirow{4}{*}{$\mathrm{SCv}$ vs. $\mathrm{CCv}$} & id_4207_273_38_X4 & Germin-like protein & 1.343 & 1.311 \\
\hline & id_202_929_37_X2 & High-affinity nitrate transporter & 1.234 & 1.935 \\
\hline & id_4563_652_35_X2 & Serine-threonine protein kinase, plant-type & 1.074 & 1.043 \\
\hline & id_1806_622_35_X2 & Aconitase & -2.147 & -1.701 \\
\hline
\end{tabular}

${ }^{\mathrm{z}}$ The comparison, probe identification (ID probe), sequence description, fold change (FC) related to the expression level after the microarray hybridization, and real-time reverse transcription (RT)-polymerase chain reaction (PCR) ratio are indicated.

yTranscripts in bold described in the "Results" and "Discussion."

Further investigations are needed to clarify this unexpected behavior.

\section{Trees growing in the field trials}

EXPRESSION ANALYSES OF A SELECT GROUP OF GENES. Table 2 shows the different Fe sensitivity of the selected rootstocks (Reforgiato Recupero et al., 2009). Sour orange was also included in this list, because it was the most commonly grown rootstock in Italian citriculture, until the appearance of CTV, as a result of its tolerance of cold, salinity, and calcareous soils. The standard rootstocks SC and CC were used to compare the behavior of the field-grown plants and the pot-grown plants. Physiological parameters were evaluated to determine the plant status. In particular, FCR activity in the roots was higher in the tolerant rootstocks than in sensitive ones (Table 8). The observed lower FCR values in the sensitive rootstocks could be the result of a greater requirement for $\mathrm{Fe} 3+$ reduction to $\mathrm{Fe} 2+$ to use the Fe present in the soil. POD activity analyses, SPAD index quantification, Fe level analyses, and total chlorophyll analyses were also performed on the leaves, and higher values were observed in the tolerant rootstocks compared with the sensitive rootstocks (Table 8).

An expression analysis of a select group of genes involved in the response to Fe deficiency was performed using real-time RT-PCR on the roots from the selected stocks. The genes encoding GPX (id_2189) and SAUR (id_2509) family proteins were considered because they were included in the overexpressed genes found in SC in the previous experiment, particularly when grown in calcareous conditions (Table 5). Root gene expression analysis (Fig. 4) confirmed the observed

Table 8. Analysis of parameters to evaluate the effect of seven citrus rootstocks in the field under natural chlorotic conditions. ${ }^{2}$

\begin{tabular}{|c|c|c|c|c|c|}
\hline \multirow[b]{3}{*}{ Rootstock } & \multirow{3}{*}{$\begin{array}{c}\text { Roots } \\
\text { FCR }\left[\mathrm{Fe}^{2+}\right. \\
\left.\left(\mu \mathrm{mol} \cdot \mathrm{g}^{-1} \cdot \mathrm{h}^{-1} \mathrm{FW}\right)\right]\end{array}$} & \multirow{2}{*}{\multicolumn{4}{|c|}{ Leaves }} \\
\hline & & & & & \\
\hline & & $\mathrm{POD}\left(\mathrm{U} \cdot \mathrm{g}^{-1} \mathrm{FW}\right)$ & $\mathrm{Chl}_{\text {tot }}\left(\mathrm{mg} \cdot \mathrm{g}^{-1} \mathrm{FW}\right)$ & $\mathrm{Fe}\left(\mathrm{mg} \cdot \mathrm{kg}^{-1} \mathrm{DW}\right)$ & SPAD index \\
\hline Swingle citrumelo & $0.099 \mathrm{ABC}$ & $6.733 \mathrm{~A}$ & $0.605 \mathrm{~A}$ & $32.900 \mathrm{AB}$ & $29.400 \mathrm{~A}$ \\
\hline C. latipes $\times P$. trifoliata $6-17$ & $0.073 \mathrm{~A}$ & $4.297 \mathrm{~A}$ & $0.430 \mathrm{~A}$ & $27.166 \mathrm{~A}$ & $25.600 \mathrm{~A}$ \\
\hline Citrus aurantium Cassibile 2 & $0.195 \mathrm{D}$ & $17.024 \mathrm{~B}$ & $2.862 \mathrm{~B}$ & $49.066 \mathrm{~B}$ & $78.500 \mathrm{~B}$ \\
\hline C. latipes $\times$ C. aurantium 13-23 & $0.127 \mathrm{BC}$ & $16.241 \mathrm{~B}$ & $2.630 \mathrm{~B}$ & $47.000 \mathrm{~B}$ & $77.633 \mathrm{~B}$ \\
\hline C. latipes $\times$ C. aurantium 14-37 & $0.145 \mathrm{CD}$ & $16.032 \mathrm{~B}$ & $2.576 \mathrm{~B}$ & $40.233 \mathrm{AB}$ & $78.266 \mathrm{~B}$ \\
\hline
\end{tabular}

${ }^{\mathrm{z}}$ Ferric-chelate reductase (FCR) was determined on roots; peroxidase (POD), total content of chlorophyll (Chl $\left.{ }_{\text {tot }}\right)$, iron (Fe) content, and SPAD index on scion leaves. Analysis of variance and mean separation was performed with Tukey's honestly significant difference test $(P \leq 0.001)$. $\mathrm{FW}=$ fresh weight. 

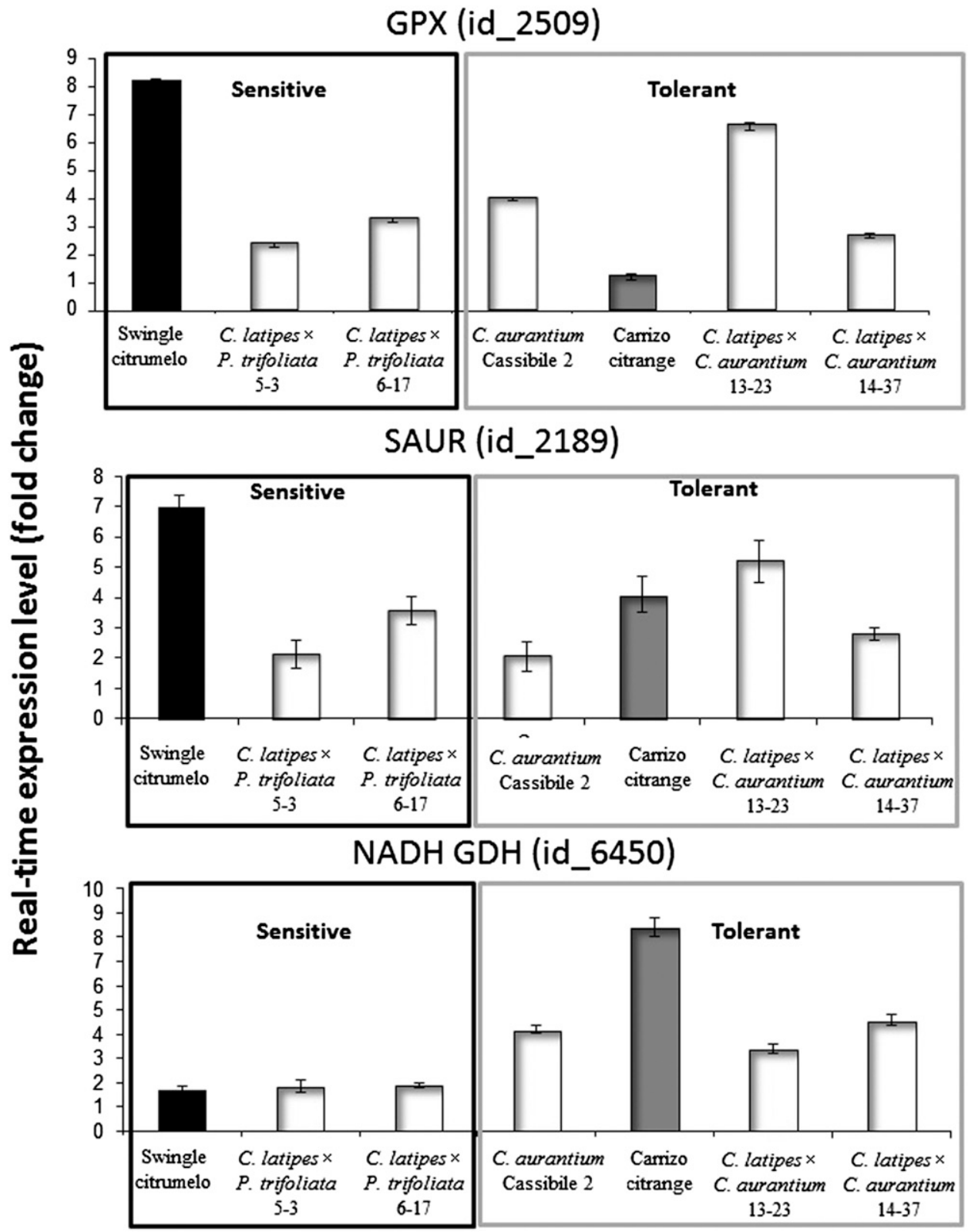

Rootstock sampling

Fig. 4. Real-time reverse transcription (RT)-polymerase chain reaction (PCR) expression data related to glutathione peroxidase (GPX), small auxin up RNA (SAUR) family gene protein, and NADH glutamate dehydrogenase (GDH) on roots of seven sensitive and tolerant Citrus and Poncirus rootstocks on the field.

The overexpression of the SAUR gene in SC plants, as compared with CC plants, could indicate an attempt to increase the root length. Plants have evolved mechanisms to facilitate $\mathrm{Fe}$ uptake in response to $\mathrm{Fe}$ deficiency. Because of this, Römheld and Marschner (1981) reported that Fe-deficient sunflower roots produced higher levels of auxin than Fe-sufficient ones. Moreover, it was suggested (Wu et al., 2012) that the primary perception of the Fe deficiency signal is determined by the roots, and auxin acts as a signal for long-distance transmission.

Among the down-regulated genes in SC, with respect to $\mathrm{CC}$, under calcareous conditions in the pot experiment, we chose to validate NADH GDH (id_6450), and we confirmed its down-regulation in all the sensitive rootstocks with respect to the tolerant ones.

Generally, there was no trend in gene expression among the sensitive and tolerant rootstocks, and this could be the result of the different genetic backgrounds associated with the different crosses.

Evaluation of aconitase ISOFORM EXPRESSION IN THE ROOTS AND JUICE. Aconitase is known to be involved in the acidification process in both citrus roots and fruits (FornerGiner and Ancillo, 2011; Shlizerman et al., 2007). Aconitase belongs to a family of enzymes that catalyze the conversion of citrate to isocitrate, and these enzymes require Fe for activation (Forner-Giner and Ancillo, 2011). The aconitate hydratase family has been described in Citrus (Terol et al., 2010), and a phylogenetic analysis clarified the evolutionary history of this protein family in plants. Moreover, the role of the citrus aconitase genes in acid homeostasis has been investigated in several acidic

increase in gene expression levels in the sensitive SC vs. the tolerant CC despite the lack of a regular expression trend among the other sensitive and tolerant rootstocks. GPX expression levels were associated with the effects of Fe deficiency-related oxidative damage. Therefore, together with the antioxidants ascorbic acid and glutathione, ROS-scavenging enzymes such as superoxide dismutase, ascorbate peroxidase, catalase, and GPX work to detoxify $\mathrm{O}_{2}{ }^{-}$and $\mathrm{H}_{2} \mathrm{O}_{2}$. The correct balance among the scavenging enzymes in cells prevents the formation of the highly toxic $\mathrm{HO}^{-}$radical. In this sense, the overexpression of GPX results in abiotic stress tolerance in various crop plants as a result of its ROS-scavenging capacity (Yousuf et al., 2012). and acidless genotypes (Terol et al., 2010). Two isoforms of aconitase have been detected: the mitochondrial form, which is involved in the tricarboxylic acid cycle, and the cytosolic form, which participates in cytosolic citrate metabolism (Cercos et al., 2006) and in the glyoxylate cycle (Hayashi et al., 1995). Real-time RT-PCR was performed to evaluate the expression of id_1806, which encodes an aconitase, and the results showed higher expression levels in the $\mathrm{CC}$ roots than in the SC roots despite the lack of expression trends in other sensitive and tolerant rootstocks (Fig. 5). These data confirmed the analysis performed with Aco3 in the field trial (Fig. 5). Reduced aconitase levels in sensitive rootstocks have also been documented by Hortschansky et al. (2007). Shlizerman et al. 


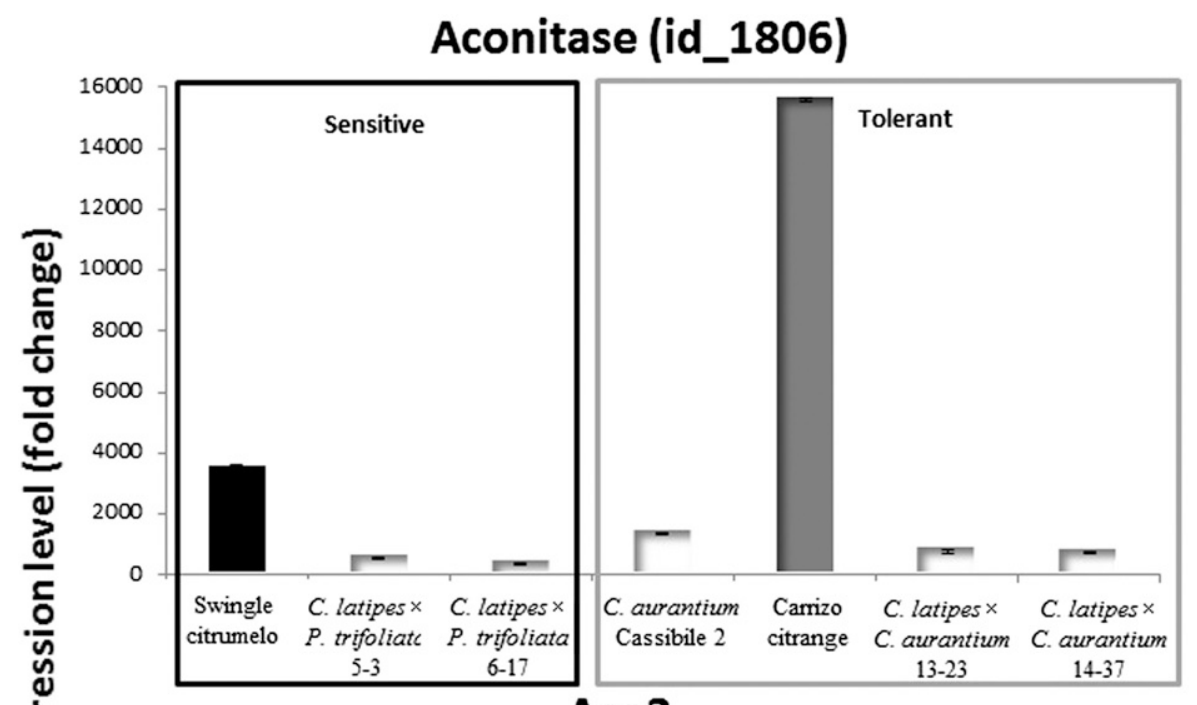

Aco3
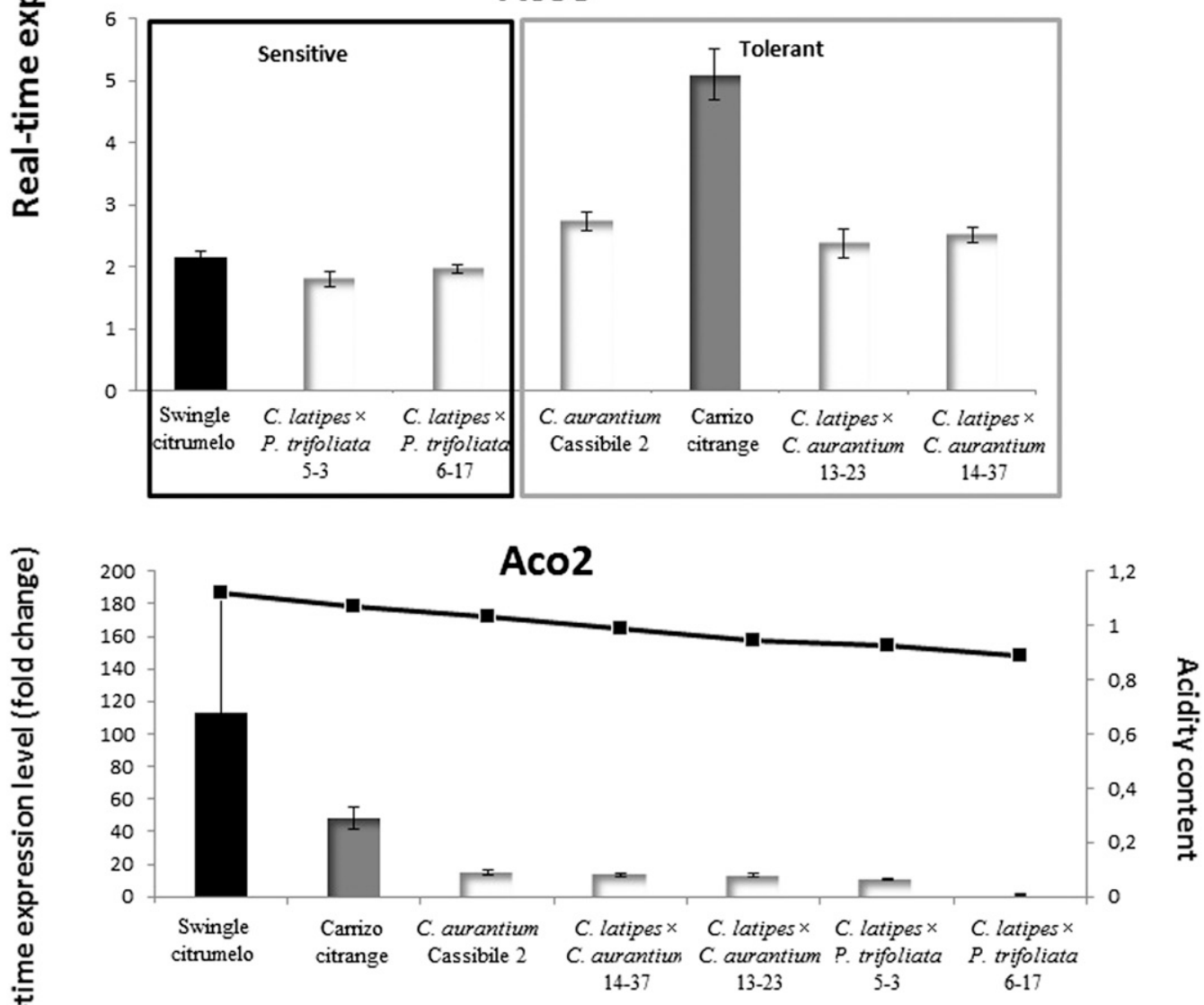

\section{Rootstock sampling}

Fig. 5. Expression data performed using the real-time reverse transcription (RT)-polymerase chain reaction (PCR) on the aconitase (id_1806) and cytosolic isoform of aconitase (Ac03) on roots of seven sensitive and tolerant Citrus and Poncirus rootstocks grown in the field. The expression data of mitochondrial isoform of aconitase (Aco2) were associated to acidity content of juice taken from fruits of scion grafted on same rootstocks.

(2007) discussed the reduction in cytosolic aconitase levels in response to limited Fe availability; this reduction results in slower rates of citrate breakdown and a concomitant increase in citrate levels. When the Fe supply is limited, aconitase activity is reduced (Shlizerman et al., 2007) as a result of the reduced levels of available $\mathrm{Fe}$ for aconitase activation. Real-time
RT-PCR analysis of the juices from plants grafted onto different rootstocks revealed the overexpression of Aco2 in $\mathrm{SC}$, with respect to $\mathrm{CC}$, which correlated with the levels of fruit acidity (Fig. 5). These data agree with previously described results from Terol et al. (2010). As reported in Shlizerman et al. (2007), we postulated that Fe deficiency induced an increase in 
the citric acid content of the juice and in mitochondrial aconitase (Aco2), which was associated with the inhibition of cytosolic aconitases such as Aco3 and id_1806.

\section{Concluding Remarks}

In most studies concerning the identification of genes involved in Fe deficiency, the plants were grown hydroponically or on in vitro substrates and were irrigated with Hoagland solution with or without EDTA-Fe. Our intent was to use natural growth conditions (in pots and in the field) to identify changes in gene expression that were representative of the conditions in which citrus rootstocks are normally grown.

The experimental design was constructed to permit the identification of genes specifically related to the genotype and Fe deficiency. The use of rootstocks in the field, in addition to those grown in pots, allowed us to hypothesize a more complex mechanism for Fe deficiency rather than a generalized explanation for the stress response. In particular, the rootstocks used in the field test were derived from a cross in which the female parent (Citrus latipes) was different from that of the CC (C. sinensis) or SC (C. paradisi). This observation supports the hypothesis that a different genetic background might be responsible for the various mechanisms involved in Fe deficiency. The validation of the pivotal genes in the field-grown plants revealed changes in gene expression that did not correlate well with their tolerant or sensitive phenotypes. These findings support the hypothesis that the genetic background determines the involvement of specific genes in the response to Fe restriction. Furthermore, our data could suggest that pathways involved in Fe deficiency tolerance in citrus are rather numerous and that different adaptation mechanisms become more or less relevant depending on the particular genetic background. The high number of unannotated genes in both of the comparisons should be investigated, perhaps using a proteomic approach.

\section{Literature Cited}

Abadía, J. and A. Abadía. 1993. Iron and pigments, p. 327-343. In: Barton, L.L. and B.C. Hemming (eds.). Iron chelation in plants and soil microorganism. Academic Press, San Diego, CA.

Abadía, J., A. Alvarez-Fernandez, A.D. Rombolà, M. Sanz, M. Tagliavini, and A. Abadía. 2004. Technologies for the diagnosis and remediation of Fe deficiency. Soil Sci. Plant Nutr. 50:965-971. Albano, J.P. and W.B. Miller. 1996. Iron deficiency stress influences physiology of iron acquisition in marigold (Tagetes erecta L.). J. Amer. Soc. Hort. Sci. 121:438-441.

Almansa, M.S., J.A. Hernandez, A. Jimenez, M.A. Botella, and F. Sevilla. 2002. Effect of salt stress on the superoxide dismutase activity in leaves of Citrus limonum in different rootstock-scion combinations. Biol. Plant. 45:545-549.

Ancillo, G., J. Gadea, J. Forment, J. Guerri, and L. Navarro. 2007. Class prediction of closely related plant varieties using gene expression profiling. J. Expt. Bot. 58:1927-1933.

Arnon, D. 1949. Copper enzymes in chloroplasts. Polyphenoloxidase in Beta vulgaris. Plant Physiol. 24:1-15.

Benjamini, Y. and Y. Hochberg. 1995. Controlling the false discovery rate: A practical and powerful approach to multiple testing. J. R. Stat. Soc., B 57:289-300.

Bienfait, H.F., R.J. Bino, A.M. van der Blick, J.F. Duivenvoorden, and J.M. Fontaine. 1983. Characterization of ferric reducing activity in roots of Fe-deficient Phaseolus vulgaris. Physiol. Plant. 59:190-202.

Bolstad, B. 2001. Probe level quantile normalization of high density oligonucleotide array data. 1 May 2013. <http://bmbolstad.com/ stuff/qnorm.pdf>.
Briat, J.F., I. Fobisloisy, N. Grignon, S. Lobreaux, N. Pascal, G. Savino, S. Thoiron, N. von Wiren, and O. van Wuytswinkel. 1995. Cellular and molecular aspects of iron metabolism in plants. Biol. Cell 84:69-81.

Brumbarova, T., A. Matros, H.P. Mock, and P. Bauer. 2008. A proteomic study showing differential regulation of stress, redox regulation and peroxidase proteins by iron supply and the transcription factor FER. Plant J. 54:321-334.

Carpena-Artes, O., J.J. Moreno, J.J. Lucena, and R.O. Carpena-Ruiz. 1995. Response to iron chlorosis of different hydroponically grown citrus varieties, p. 147-151. In: Abadía, J. (ed.). Iron nutrition in soils and plants. Kluwer Academic Publisher, Dordrecht, The Netherlands. Cercos, M., G. Soler, D.J. Iglesias, J. Gadea, J. Forment, and M. Talon. 2006. Global analysis of gene expression during development and ripening of citrus fruit flesh. A proposed mechanism for citric acid utilization. Plant Mol. Biol. 62:513-527.

Chen, W.W., J.L. Yang, C. Qin, C.W. Jin, J.H. Mo, T. Ye, and S.J. Zheng. 2010. Nitric oxide acts downstream of auxin to trigger root ferric-chelate reductase activity in response to iron deficiency in Arabidopsis. Plant Physiol. 154:810-819.

Chouliaras, V., I. Therios, A. Molassiotis, A. Patakas, and G. Diamantidis. 2004. Effect of iron deficiency on gas exchange and catalase and peroxidase activity in citrus. J. Plant Nutr. 27:2085-2099.

Conesa, A., S. Gotz, J.M. Garcia-Gomez, J. Terol, M. Talon, and M. Robles. 2005. Blast2GO: A universal tool for annotation, visualization and analysis in functional genomics research. Bioinformatics 21:3674-3676.

Donnini, S., B. Prinsi, A.S. Negri, G. Vigani, L. Espen, and G. Zocchi. 2010. Proteomic characterization of iron deficiency responses in Cucumis sativus L. roots. BMC Plant Biol. 10:268.

Edgar, R., M. Domrachev, and A.E. Lash. 2002. Gene expression omnibus: NCBI gene expression and hybridization array data repository. Nucleic Acids Res. 30:207-210.

Fang, W.C. and C.H. Kao. 2000. Enhanced peroxidase activity in rice leaves in response to excess iron, copper and zinc. Plant Sci. 158:71-76.

Fernandez-Escobar, R., D. Barranco, and M. Benlloch. 1993. Overcoming iron chlorosis in olive and peach-trees using a low-pressure trunk-injection method. HortScience 28:192-194.

Forner-Giner, M.A. and G. Ancillo. 2011. Iron stress in citrus, p. 165178. In: Vasanthaiah, H. (ed.). Plants and environment. 1 May 2013. $<$ http://www.intechopen.com/books/plants-and-environment/ironstress-in-citrus $>$.

Forner-Giner, M.A., M.J. Llosa, J.L. Carrasco, M.A. Perez-Amador, L. Navarro, and G. Ancillo. 2010. Differential gene expression analysis provides new insights into the molecular basis of iron deficiency stress response in the citrus rootstock Poncirus trifoliata (L.). Raf. J. Expt. Bot. 61:483-490.

Git, A., H. Dvinge, M. Salmon-Divon, M. Osborne, C. Kutter, J. Hadfield, P. Bertone, and C. Caldas. 2010. Systematic comparison of microarray profiling, real-time PCR, and next-generation sequencing technologies for measuring differential microRNA expression. RNA 16:991-1006.

Guerinot, M.L. and Y. Yi. 1994. Iron: Nutritious, noxious, and not readily available. Plant Physiol. 104:815-820.

Hamze, M., J. Ryan, and M. Zaabout. 1986. Screening of citrus rootstocks for lime-induced chlorosis tolerance. J. Plant Nutr. 9:459469.

Hayashi, M., L. Debellis, A. Alpi, and M. Nishimura. 1995. Cytosolic aconitase participates in the glyoxylate cycle in etiolated pumpkin cotyledons. Plant Cell Physiol. 36:669-680.

Hiscox, J. and G. Israelstam. 1979. A method for the extraction of chlorophyll from leaf tissue without maceration. Can. J. Bot. 57:1332-1334.

Hortschansky, P., M. Eisendle, Q. Al-Abdallah, A.D. Schmidt, S. Bergmann, M. Thon, O. Kniemeyer, B. Abt, B. Seeber, E.R. Werner, M. Kato, A.A. Brakhage, and H. Haas. 2007. Interaction of HapX with the CCAAT-binding complex-A novel mechanism of gene regulation by iron. EMBO J. 26:3157-3168. 
Intrigliolo, F., A. Giuffrida, P. Rapisarda, M. Calabretta, and G. Roccuzzo. 2000. SPAD as an indicator of nitrogen status in citrus. Proc. Intl. Soc. Citricult. IX Congr. p. 665-667.

Jaegger, B., H. Goldbach, and K. Sommer. 2000. Release from lime induced iron chlorosis by CULTAN in fruit trees and its characterization by analysis. Acta Hort. 107-113.

Klok, E.J., I.W. Wilson, D. Wilson, S.C. Chapman, R.M. Ewing, S.C. Somerville, W.J. Peacock, R. Dolferus, and E.S. Dennis. 2002. Expression profile analysis of the low-oxygen response in Arabidopsis root cultures. Plant Cell 14:2481-2494.

Licciardello, C., M.P. Russo, G. Valè, and G. Reforgiato Recupero. 2008. Identification of differentially expressed genes in the flesh of blood and common oranges. Tree Genet. Genomes 4:315-331.

Loupassaki, M.H., S.M. Lionakis, and I.I. Androulakis. 1997. Iron deficiency in kiwi and its correction by different methods. Acta Hort. 444:267-271.

Marschner, H. 1995. Mineral nutrition of higher plants. 2nd Ed. Academic Press, Cambridge, UK.

Melo-Oliveira, R., I.C. Oliveira, and G.M. Coruzzi. 1996. Arabidopsis mutant analysis and gene regulation define a nonredundant role for glutamate dehydrogenase in nitrogen assimilation. Proc. Natl. Acad. Sci. USA 93:4718-4723.

Mengel, K. 1994. Iron availability in plant-tissues: Iron chlorosis on calcareous soils. Plant Soil 165:275-283.

Mengel, K., E. Kirkby, H. Kosegarten, and T. Appel. 2001. Principles of plant nutrition. Kluwer Academic Publishers, Dordrecht, The Netherlands.

Morales, F., A. Abadía, and J. Abadía. 1998. Photosynthesis, quenching of chlorophyll fluorescence and thermal energy dissipation in iron-deficient sugar beet leaves. Aust. J. Plant Physiol. 25:403-412.

Muller, M. and W. Schmidt. 2004. Environmentally induced plasticity of root hair development in Arabidopsis. Plant Physiol. 134:409-419. Ngo, T.T. and H.M. Lenhoff. 1980. A sensitive and versatile chromogenic assay for peroxidase and peroxidase-coupled reactions. Anal. Biochem. 105:389-397.

Nxawe, S., P.A. Ndakidemi, and C.P. Laubsche. 2011. Chlorophyll pigmentation and photosynthetic parameters in Ornithogalum longibracteatum $\mathrm{L}$. as affected by varying temperatures in hydroponics solution. Intl. J. Physical Sci. 6:2965-2972.

Passardi, F., C. Cosio, C. Penel, and C. Dunand. 2005. Peroxidases have more functions than a Swiss army knife. Plant Cell Rpt. 24:255-265.

Pedas, P., C.K. Ytting, A.T. Fuglsang, T.P. Jahn, J.K. Schjoerring, and S. Husted. 2008. Manganese efficiency in barley: Identification and characterization of the metal ion transporter HvIRT1. Plant Physiol. 148:455-466.

Peret, B., B. De Rybel, I. Casimiro, E. Benkova, R. Swarup, L. Laplaze, T. Beeckman, and M.J. Bennett. 2009. Arabidopsis lateral root development: An emerging story. Trends Plant Sci. 14:399-408.

Pérez-Sanz, A., A. Álvarez-Fernandez, T. Casero, F. Legaz, and J.J. Lucena. 2002. Fe enriched biosolids as fertilizers for orange and peach trees grown in field conditions. Plant Soil 241:145-153.

Perry, P., B. Linke, and W. Schmidt. 2007. Reprogramming of root epidermal cells in response to nutrient deficiency. Biochem. Soc. Trans. 35:161-163.

Pertea, G., X.Q. Huang, F. Liang, V. Antonescu, R. Sultana, S. Karamycheva, Y. Lee, J. White, F. Cheung, B. Parvizi, J. Tsai, and J. Quackenbush. 2003. TIGR Gene Indices clustering tools (TGICL): A software system for fast clustering of large EST datasets. Bioinformatics 19:651-652.

Pestana, M., P.J. Correia, M. David, A. Abadía, J. Abadía, and A. de Varennes. 2011. Response of five citrus rootstocks to iron deficiency. J. Plant Nutr. Soil Sci. 174:837-846.

Pestana, M., A. de Varennes, and E. Faria. 2003. Diagnosis and correction of iron chlorosis in fruit trees: A review. J. Food Agr. Environ. 1:46-51.

Reforgiato Recupero, G., G. Russo, S. Recupero, R. Zurru, B. Deidda, and M. Mulas. 2009. Horticultural evaluation of new Citrus latipes hybrids as rootstocks for Citrus. HortScience 44:595-598.
Rellán-Álvarez, R., S. Andaluz, J. Rodriguez-Celma, G. Wohlgemuth, G. Zocchi, A. Álvarez-Fernandez, O. Fiehn, A.F. Lopez-Millan, and J. Abadía. 2010. Changes in the proteomic and metabolic profiles of Beta vulgaris root tips in response to iron deficiency and resupply. BMC Plant Biol. 10:120.

Robinson, S.A., A.P. Slade, G.G. Fox, R. Phillips, R.G. Ratcliffe, and G.R. Stewart. 1991. The role of glutamate dehydrogenase in plant nitrogen metabolism. Plant Physiol. 95:509-516.

Rombolà, A.D., M. Quartieri, B. Marangoni, M. Tagliavini, D. Scudellari, and J. Abadì. 1999. Strategie di cura della clorosi ferrica nella frutticoltura integrata. Frutticoltura 5:59-64.

Romera, F., M. García, E. Alcántara, and R. Pérez-Vicente. 2011. Latest findings about the interplay of auxin, ethylene and nitric oxide in the regulation of Fe deficiency responses by strategy I plants. Plant Signal. Behav. 6:167-170.

Römheld, V. and D. Kramer. 1983. Relationship between proton efflux and rhizodermal transfer cells induced by iron deficiency. Zeitschrift für Pflanzenphysiologie 113:73-83.

Römheld, V. and H. Marschner. 1981. Rhythmic iron stress reactions in sunflower at suboptimal iron supply. Physiol. Plant. 53:347-353.

Rouillard, J.M., M. Zuker, and E. Gulari. 2003. OligoArray 2.0: Design of oligonucleotide probes for DNA microarrays using a thermodynamic approach. Nucleic Acids Res. 31:3057-3062.

Sanz, M., J. Pascual, and J. Machìn. 1997. Prognosis and correction of iron chlorosis in peach trees: Influence on fruit quality. J. Plant Nutr. 20:1567-1572.

Schmidt, W., W. Michalke, and A. Schikora. 2003. Proton pumping by tomato roots. Effect of Fe deficiency and hormones on the activity and distribution of plasma membrane H+-ATPase in rhizodermal cells. Plant Cell Environ. 26:361-370.

Shlizerman, L., K. Marsh, E. Blumwald, and A. Sadka. 2007. Ironshortage-induced increase in citric acid content and reduction of cytosolic aconitase activity in Citrus fruit vesicles and calli. Physiol. Plant. 131:72-79.

Srivastava, H.S. and R.P. Singh. 1987. The role and regulation of L-glutamate dehydrogenase activity in higher plants. Phytochemistry 26:597-610.

Slatni, T., A. Krouma, S. Aydi, C. Chaiffi, H. Gouia, and C. Abdelly. 2008. Growth, nitrogen fixation and ammonium assimilation in common bean (Phaseolus vulgaris L) subjected to iron deficiency. Plant Soil 312:49-57.

Smyth, G. 2005. Limma: Linear models for microarray data, p. 397420. In: Carey, R., V. Dudoit, S. Irizarry, and W. Huber (eds.). Bioinformatics and computational biology solutions using $\mathrm{R}$ and Bioconductor. Springer, New York, NY.

Sweet Orange Genome Project. 2010. Citrus sinensis (sweet orange). 1 Feb. 2012. <http://www.phytozome.net/citrus.php>.

Terol, J., G. Soler, M. Talon, and M. Cercos. 2010. The aconitate hydratase family from Citrus. BMC Plant Biol. 10:222.

Vigani, G., A. Chittò, P. De Nisi, and G. Zocchi. 2012. cDNA-AFLP analysis reveals a set of new genes differentially expressed in cucumber root apexes in response to iron deficiency. Biol. Plant. 56:502-508.

Wu, T., H-T. Zhang, Y. Wang, W-S. Jia, X-F. Xu, X-Z. Zhang, and Z.H. Han. 2012. Induction of root Fe(III) reductase activity and proton extrusion by iron deficiency is mediated by auxin-based systemic signalling in Malus xiaojinensis. J. Expt. Bot 63:859-870. Yousuf, P.Y., K.U. Rehman, H.R. Chandna, and P. Ahmad. 2012. Role of glutathione reductase in plant abiotic stress, p. 149-158. In: Ahmad, P. and M.N.V. Prasad (eds.). Abiotic stress responses in plants: Metabolism, productivity and sustainability. Springer Science + Business Media, New York, NY.

Zamboni, A., L. Zanin, N. Tomasi, M. Pezzotti, R. Pinton, Z. Varanini, and S. Cesco. 2012. Genome-wide microarray analysis of tomato roots showed defined responses to iron deficiency. BMC Genomics 13:101. Zheng, L.Q., F.L. Huang, R. Narsai, J.J. Wu, E. Giraud, F. He, L.J. Cheng, F. Wang, P. Wu, J. Whelan, and H.X. Shou. 2009. Physiological and transcriptome analysis of iron and phosphorus interaction in rice seedlings. Plant Physiol. 151:262-274. 